\title{
Awakening the Intuitive Mind: Self-Cultivation in the Practical Philosophies of Wang Yangming and Sri Aurobindo
}

\author{
Richard HARTZ \\ Editor, Archives and Research Library, Sri Aurobindo Ashram, Pondicherry, \\ India \\ richardahartz@hotmail.com
}

\begin{abstract}
Sri Aurobindo lived four hundred years after Wang Yangming in a different civilization and another age. Yet there are parallels between the lives of these two thinkers and significant similarities between their philosophies. Central to the methods of practice advocated by both is the uncovering of a faculty of knowledge which we already possess, but normally allow to be obscured by our ordinary psychological movements. This faculty, the intuitive mind, has to emerge and be applied to all the activities of life. Methods for cultivating it have been developed under different names in both China and India. They can be found in ancient texts such as the Great Learning and the Bhagavadgitā as well as in the writings of Wang Yangming and Sri Aurobindo. Integral education would be incomplete if it does not include the cultivation of the intuitive mind.
\end{abstract}

\section{Keywords}

Neo-Confucianism - Neo-Vedanta - liangzhi-xiushen - integral education

Our human quest for knowledge to enable us to meet the challenges of life has generally followed either of two main lines. One way to proceed is to begin by looking outward at the world we perceive through our senses and to apply 
the faculty of reason to make sense of the information so obtained. By these means, it is hoped that we will gradually be able to increase our understanding of the universe we live in, determine our relationship to it and to each other, and exercise the power this knowledge gives. Alternatively, we can start by concentrating on the immediate experience of our own existence and see where that leads us. Pursuing this inner exploration, perhaps we may get more directly at the heart of things by developing an intuitive insight which can then be turned upon the external world as well.

These two methods are not mutually exclusive. It can be argued that both are equally necessary. But throughout history, different cultures have tended to emphasize one or the other. In recent times, the West has carried the search for objective, scientific knowledge to its limits. On the other hand, the peoples of the East have often been more inclined to embark on the adventure of subjective self-discovery. Within each civilization, however, both approaches have always co-existed, even if one has predominated.

By and large, the preferred instrument of knowledge in the West has been the rational intellect working on the data supplied by the physical senses. Systematizing this approach in the scientific method, the West has changed the world with its astonishing advances in understanding and mastering the laws of material Nature. But the breakneck pace of these developments has created at least as many problems as it has solved. In contrast, the contributions of the slower-paced and longer-lasting civilizations of the East have pertained more to the inner life and the possibilities of a transcendence or transformation of our normal human condition. After a period of decline and eclipse, Asia now seems poised to resume its place at the forefront of human progress. But in order to continue its evolution and fulfil its potential, it must outgrow the imitation of Western models and rediscover its own genius.

China and India are not only the most populous nations in Asia and the world, but represent the oldest civilizations on earth, with long and unbroken histories of achievement in every sphere of culture. Not surprisingly, these two countries provide some of the best examples of the value of Eastern practices that cultivate intuition as a source of enlightenment. I will focus on the Neo-Confucian master, Wang Yangming (1472-1529), and the modern Indian philosopher and mystic, Sri Aurobindo (1872-1950). Though they lived in very different times 
and circumstances, a comparison of these two figures in Chinese and Indian history, philosophy and spirituality reveals significant parallels.

The ethical, socio-political and educational philosophy traced to Confucius (Kongzi, 551-479 BCE) has shaped the Chinese mind in a manner that no other way of thought has been able to rival in the long run. Nevertheless, after reaching a peak of influence during the Han Dynasty (206 BCE-220 CE), when it was enshrined as an official ideology, Confucianism became increasingly scholastic and lost some of its appeal. Meanwhile, Daoism and Buddhism grew in popularity. In response to this situation and in creative tension and dialogue with these other systems, often viewed as complementary rather than conflicting, what is now called Neo-Confucianism emerged and flourished in the Song (960-1279) and Ming Dynasties (1368-1644).

During the middle years of the Ming, Wang Shouren (later known as Wang Yangming) was born in a small town near Shaoxing in Zhejiang Province of southeastern China. Early in his life he came under the spell of Daoism. He was also attracted to Buddhist methods of meditation. He maintained a life-long affinity with both of these contemplative disciplines, but in the end could not find in them the harmony of individual aspiration and social commitment which is the strength of Confucianism. He devoted himself, therefore, to the Neo-Confucian synthesis elaborated a few centuries earlier by the great thinker Zhu Xi (1130-1200). But eventually he became dissatisfied with Zhu Xi's doctrine as well and set out to find his own way to the Confucian goal of sagehood.

The turning point was a revelation one night in the summer of 1508 . He was living at the time in a hut in the wilderness. As a government official in Beijing, he had protested against abuses of power by the notorious Liu Jin, a eunuch who was then ruling in place of the young emperor. For this he had been imprisoned, subjected to brutal punishment, publicly humiliated and banished to a remote region. Under these circumstances, while meditating in the middle of the night, he had a powerful experience. The biographer Bresciani gives this account of it: "His brain was overwhelmed by a sudden conviction, namely that the source of truth and goodness lay nowhere else but in our minds.... By logical consequence, becoming a sage simply meant uncovering one's conscience from all erroneous thoughts and selfish impulses" (2016). This insight led him to turn away from Zhu Xi's emphasis on book-learning and the search for truth outside oneself by rational inquiry. Now he began to follow his own path and develop an original teaching, supported by his interpretation of the Confucian classics. 
Wang Yangming's relation to these classics was not unlike Sri Aurobindo's relation to the Upanishads and other Sanskrit texts such as the Bhagavadgit $\bar{a}$ which are regarded as scriptures of Hinduism. Both were inspired and guided by their chosen texts up to a certain point, yet did not hesitate to go beyond them if necessary on the basis of personal experience. Sri Aurobindo's case was unusual. Though Indian by birth, he grew up with almost no exposure to his own tradition. Born as Aurobindo Ghose in Calcutta at a time when much of Asia had fallen under the domination of Europe, at the age of seven he was sent to England for his education. Returning to India when he was twenty, it was during the next decade and a half that he discovered and assimilated the riches of his native culture.

Toward the end of this period, he emerged as a leader of the first phase of India's struggle for freedom from foreign rule. In 1908-9, he spent a year in prison for his anti-colonial activism. He was then the same age as Wang Yangming had been when he endured imprisonment and exile. In an even more striking parallel, it was under these adverse conditions that Sri Aurobindo had the spiritual realizations which altered the direction of his life. A few months after his release from jail, he left the scene of his political activities in Bengal and travelled to the French colony of Pondicherry on the southeast coast of India. There he spent the remaining forty years of his life developing his philosophy and his method of spiritual practice, the Integral Yoga, beyond the reach of the British government. During this time he wrote most of the works for which he is known today, synthesizing East and West and presenting Indian thought to the world.

\section{$3 \quad$ Neo-Confucianism and Neo-Vedanta}

Sri Aurobindo's philosophy is sometimes called Neo-Vedantic, just as Wang Yangming's is often referred to as Neo-Confucian. These terms can be useful but need to be clarified. In the long history of Confucianism, three distinct periods are commonly identified, with transitions between them: "Classical Confucianism," the founding period of Confucius himself, Mencius (Mengzi, 371-289 вСE) and others; the "Neo-Confucian" revival of the Song and Ming Dynasties, reaching its peaks in Zhu Xi and Wang Yangming; and the twentieth-century renaissance in response to the Western impact, known as "New Confucianism" and represented by philosophers such as Mou Zongsan (1909-95) and several of his contemporaries.

Three periods in the history of Vedanta can similarly be distinguished, though there are no equally convenient and generally accepted terms for this 
purpose. The word Vedānta itself literally refers to the ancient texts that come at the end (anta) of the Veda, namely, the Upanishads. ${ }^{1}$ When Sri Aurobindo speaks of "the original Vedanta, not of the schools of metaphysical philosophy, but of the Upanishads" (2005, p. 16), he is insisting on this sense of Vedanta. But in accounts of the main systems of Indian philosophy, it is often to the later "schools of metaphysical philosophy," such as the Advaita Vedanta of Shankara (eighth century CE), that the term Vedanta is applied. Yet the distance in time and difference in content between the earlier and later Vedanta would justify describing philosophers like Shankara as Neo-Vedantic. Since this designation has not acquired currency, the label "Neo-Vedanta" (if used) has been reserved for developments in the nineteenth and twentieth centuries, corresponding roughly to "New Confucianism" in China.

Such periodization inevitably oversimplifies the history of thought; but when intelligently employed, it can save us from getting lost in details and help us see the big picture. The recognition of three main periods of Vedanta, analogous to those of Confucianism, can facilitate a broad comparison of the lines of evolution of these central currents in Indian and Chinese philosophy. What stands out in such a comparison is that the differences between Confucianism and Vedanta seem to increase in the second period and diminish again in the last period. The source of this divergence can be traced, at least in part, to the role of Buddhism which is a common element in the histories of these two civilizations.

Buddhist ideas undoubtedly contributed to the emphasis of the Neo-Confucian masters on inner self-cultivation. At the same time, as Yao points out, "their system is by nature anti-Buddhist and its underlying theme is to present a powerful argument against Buddhism" (2000, p. 97). Buddhism came to be widely perceived in China as undermining the social fabric with an excessive turn toward spiritual individualism. Yet it survived, while in its country of origin it largely died out. Whatever the historical reasons for its disappearance as a formal system in India, however, something of the pessimistic worldview that critics attribute to Buddhism arguably survived and its influence is reflected in the later phase of Vedanta. Sri Aurobindo considered the asceticism and world-weariness that gradually overtook Indian spirituality to be partly a result of the combined legacy of Buddha and Shankara:

1 The Upanishads are difficult to date, but many scholars would agree that the oldest of them go back at least to the eighth century всE, followed by the other principal Upanishads in the course of the next half millennium or so. Minor, less authoritative texts calling themselves Upanishads continued to be written long after that, but do not concern us here. 
The spirit of these two remarkable spiritual philosophies - for Shankara in the historical process of India's philosophical mind takes up, completes and replaces Buddha, - has weighed with a tremendous power on her thought, religion and general mentality: everywhere broods its mighty shadow, everywhere is the impress of the three great formulas, the chain of Karma, escape from the wheel of rebirth, Maya [illusion] (2005, p. 432).

Sri Aurobindo acknowledged the positive achievements of Buddha and Shankara but opposed the life-negating implications he saw in their philosophies. Advocating a life-affirming and world-embracing spirituality consistent with the ancient Vedanta of the Upanishads, his views on the relationship between the inner and the outer life agree in many ways with those that can be found in the Confucian tradition.

\section{Ethics, Sagehood and Yoga}

Confucianism is often regarded as primarily an ethical system, Vedanta as a contemplative philosophy. While this perception is not without basis, the truth is more complex and the fact is that each shares features usually ascribed to the other. This is especially true when both are viewed as a whole in their historical and cultural contexts. To keep this comparison within the limits that space permits, I will center my discussion around Sri Aurobindo's interpretation of the Bhagavadgitta and Wang Yangming's commentary on the Confucian classic, the Great Learning (Da Xue). This juxtaposition brings out the pragmatic side of Vedanta and the contemplative dimension of Confucianism in both earlier and later stages of development.

In Essays on the Gita, Sri Aurobindo explains the unique place occupied by the Bhagavadgītā in the Indian philosophical and spiritual tradition.

The Gita is in its foundation a Vedantic work. . . and, although not described as a revealed Scripture. . it is yet so highly esteemed as to be ranked almost as a thirteenth Upanishad. But still its Vedantic ideas are throughout and thoroughly coloured by the ideas of the Sankhya and the Yoga way of thinking and it derives from this colouring the peculiar synthetic character of its philosophy. It is in fact primarily a practical system of Yoga that it teaches and it brings in metaphysical ideas only as explanatory of its practical system (1997a, p. 68). 
It is likewise for practical as well as theoretical reasons that Neo-Confucianists were so strongly attracted to the Great Learning, a short text on which they bestowed attention far out of proportion to its length. Wang Yangming's Inquiry on the Great Learning, written a year or so before the end of his life, is often said to be his most important work. It can be fruitfully compared with Sri Aurobindo's Essays on the Gita and other writings on Yoga.

The Great Learning is unique among texts of its kind in that it explicitly presents itself as a program of education, viewed as a lifelong occupation. But its conception of education is an extraordinary one, aiming at nothing short of sagehood. Its aim and method resemble, indeed, the Gita's teaching with regard to several stages on the path to the spiritual realizations attainable by an integral practice of Yoga. The Great Learning famously begins with a list of "three items," followed closely by its equally celebrated "eight steps." Together, these form as concise a summary as possible of a practical philosophy of individual self-cultivation with profound social and political ramifications.

The three items constituting the "Way" of self-education announced in the first sentence of the Great Learning are - following Wing-tsit Chan's translation, which is itself something of a modern classic - "manifesting the clear character, loving the people, and abiding in the highest good" (1969: p. 86). Wang Yangming comments at some length on each of these three phrases. First, he offers this explanation of the "clear character" (míng dé 明德) and what it means to make it manifest (ming 明):

The great man regards Heaven and Earth and the myriad things as one body. He regards the world as one family and the country as one person. As to those who make a cleavage between objects and distinguish between the self and others, they are small men.... Even the mind of the small man necessarily has the humanity that forms one body with all. Such a mind is rooted in his Heaven-endowed nature, and is naturally intelligent, clear, and not beclouded. For this reason it is called the "clear character.". . Thus the learning of the great man consists entirely in getting rid of the obscuration of selfish desires in order by his own efforts to make manifest his clear character, so as to restore the condition of forming one body with Heaven, Earth, and the myriad things (1969, pp. 659-6o).

Wang's commentary on the next item, "loving the people," brings out its close relationship with the first item, amounting to an inseparable interdependence of these two injunctions: 
Manifesting the clear character consists in loving the people, and loving the people is the way to manifest the clear character.... Everything from ruler, minister, husband, wife, and friends to mountains, rivers, spiritual beings, birds, animals, and plants should be truly loved in order to realize my humanity that forms one body with them, and then my clear character will be completely manifested, and I will really form one body with Heaven, Earth, and the myriad things (1969, pp. 66o-61).

Finally, Wang's elucidation of "abiding in the highest good" leads to an indication of the practical consequences of living in the state of consciousness just described:

The nature endowed in us by Heaven is pure and perfect. The fact that it is intelligent, clear, and not beclouded is evidence of the emanation and revelation of the highest good. It is the original substance of the clear character which is called innate knowledge of the good. As the highest good emanates and reveals itself, we will consider right as right and wrong as wrong. Things of greater or less importance and situations of grave or light character will be responded to as they act upon us. In all our changes and movements, we will stick to no particular point, but possess in ourselves the Mean that is perfectly natural. This is the ultimate of the normal nature of man and the principle of things.... Naturally, how can anyone who does not watch over himself carefully when alone, and who has no refinement and singleness of mind, attain to such a state of perfection (1969, p. 661)?

This is evidently the psychological condition described by Sri Aurobindo in which our ethical evolution culminates in "a high purity of the reason and will. .. a wide sympathy and preparation of oneness." That culmination in turn is "raised into a higher and freer light," where all our acts "will proceed naturally and spontaneously from an innate perfect will and by an inherent perfect guidance" (1977a, pp. 489-90). This is the consciousness of the "perfect sage" who, in the language of the Gita, "is ever engaged with a large equality in doing good to all creatures and makes that his occupation and delight, sarvabhütahite ratah. The perfect Yogin is no solitary musing on the Self in his ivory tower of spiritual isolation, but yukta hrtsna-karma-krt, a many-sided universal worker for the good of the world, for God in the world" (1977a, p. 199). In the highest realization on this path of the Yoga of action, Karmayoga, just as the Confucian sage feels himself to be "one body with Heaven, Earth, and the myriad things," likewise we come to "see ourself in all and all in ourself, perceive all knowledge and thought and feeling as motions of the one Mind and Heart, all energy and 
action as kinetics of the one Will in power, all Matter and form as particles of the one Body" (1999, p. 256).

\section{The Intuition of Good}

A key term in Wang Yangming's thought is liángzhī ( 良知, literally “good knowing"), translated above as "innate knowledge of the good." This is the faculty by which, "as the highest good emanates and reveals itself, we will consider right as right and wrong as wrong" (Chan, 1969, p. 661). Regarding the nature of this faculty and the possibility of cultivating it, Bresciani observes:

The character of liangzhi is intuitive. For Wang, the power of liangzhi lies in its ability properly to respond to any situation, rather than in factual knowledge that involves concrete information. . . . For Wang, who believed in the perfect, intuitive power of liangzhi, resolution to become a sage based on self-confidence was important: "There is a sage in everyone. Only, anyone who has not enough self-confidence buries his/her own chance." . . . People are no longer under the burden of any other business except for getting rid of selfish desire (2016).

"Intuitive knowledge" is a definition of liángzhī found in some dictionaries, though it has not generally been adopted by scholars of Confucianism, perhaps because of the vagueness associated with "intuition" in ordinary English usage. But the concept of intuition lies at the heart of Sri Aurobindo's epistemology and is anything but vague. Let us see how far Wang's liángzhī would qualify as intuitive knowledge in an Aurobindonian sense.

For Sri Aurobindo, intuition is a faculty which, rather than laboriously constructing representations of truth, "has only to bring the latent truth out of itself, - the perception which the old thinkers tried to express when they said that all knowing was in its real origin and nature only a memory of inwardly existing knowledge" (1999, p. 789). The "old thinkers" meant here are presumably the Greeks, especially Plato with his theory of anamnesis; but Wang Yangming's liángzhī also involves recovering an "inwardly existing knowledge." Angle points out:

Wang focuses on the idea of "discovery" of an already existing moral capacity, our liangzhi 良知, which Ivanhoe translates as "pure knowing." This capacity needs no development - it comes fully formed - although we must discover it within ourselves and clear away various obstacles to its functioning (2009, p. 115). 
The intuitive character of liángzhī, in a sense consistent with Sri Aurobindo's understanding of intuition, can be taken then as established. There remains an apparent difference between this "moral capacity" and Sri Aurobindo's usual approach to intuition, in which its cognitive function seems to be emphasized. But the nature of intuition as such, which he explains in terms of "knowledge by identity," is not affected by whether it is applied to the pursuit of truth for its own sake or for the sake of action.

Sri Aurobindo shared Wang's view of the unity of knowledge and action. Sometimes he mentions intuition in an ethical context, as when he writes: "There is only one safe rule for the ethical man, to stick to his principle of good, his instinct for good, his vision of good, his intuition of good and to govern by that his conduct" (1997b, p. 150). Accepting the intuitive character of liángzhi and keeping in mind Wing-tsit Chan's rendering of this term as "innate knowledge of the good," its essence would seem to be captured accurately enough by Sri Aurobindo's phrase "intuition of good." In a passage that sheds light on the Confucian ideal of "abiding in the highest good" (zhı̆yú zhishàn 止于至善), he goes on to speak of the role of "intuitions and inspirations" in aligning our inner being with an "absolute good":

It is difficult, even impossible to justify upon outward grounds the absolute justice, absolute right, absolute purity, love or selflessness of an action or course of action; for action is always relative, it is mixed and uncertain in its results, perplexed in its occasions. But it is possible to relate the inner being to the eternal and absolute good, to make our sense and will full of it so as to act out of its impulsion or its intuitions and inspirations (1997b, p. 153).

The three items with which the Great Learning begins - "manifesting the clear character, loving the people, and abiding in the highest good" - are followed by a passage closely related to the last of these:

Only after knowing what to abide in can one be calm. Only after having been calm can one be tranquil. Only after having achieved tranquillity can one have peaceful repose. Only after having peaceful repose can one begin to deliberate. Only after deliberation can the end be attained (CHAN, 1969, p. 86). 
The word translated here as "calm" requires clarification, because ding 定 has a range of meanings not quite matched by any one word in English. Angle translates it as "settled" (2009, p. 36). This is close to the primary sense; calm is a secondary sense resulting from the idea of settling down. Wang Yangming explains in his commentary that ding means having "definite direction" (dingxiàng 定向):

People fail to realize that the highest good is in their minds and seek it outside.... Consequently, the mind becomes fragmentary, isolated, broken into pieces; mixed and confused, it has no definite direction. Once it is realized that the highest good is in the mind and does not depend on any search outside, then the mind will have definite direction and there will be no danger of its becoming fragmentary, isolated, broken into pieces, mixed, or confused (CHAN, 1969, p. 662).

There are striking similarities here to a verse in the second chapter of the Bhagavadgita (2.41): "The fixed and resolute intelligence is one and homogeneous. . . many-branching and multifarious is the intelligence of the irresolute" (Roy, 2009, p. 47). The Sanskrit word corresponding to ding is vyavasāya, "resolution," contrasted to the movement of the dissipated intelligence which is described as "many-branching" (bahuśákhā, Wang's "fragmentary, isolated, broken into pieces"). Sri Aurobindo remarks that "it is the upward and inward orientation of the intelligent will that we must resolutely choose with a settled concentration and perseverance, ryavasāya" (1997a, p. 99). He elaborates:

The unified intelligent will is fixed in the enlightened soul, it is concentrated in inner self-knowledge; the many-branching and multifarious, busied with many things, careless of the one thing needful is on the contrary subject to the restless and discursive action of the mind (1997a, p. 96).

Once this settled condition is achieved, the stages that follow are enumerated in the Great Learning as tranquillity (jing 静), peaceful repose (ān 安), deliberation (lì 虑) and attainment of the end (dé 得). Again there are parallels with the Bhagavadgitā, especially verses $64-66$ of the second chapter. Here prasāda, translated by Sri Aurobindo as "clear tranquillity," results from bringing the senses under control. It leads to the deeper peace called śänti, creating the conditions in which "the intelligence is rapidly established [buddhih paryavatisțhate] in the peace of the self" (1997a, p. 101). In his essay "The Strength 
of Stillness," Sri Aurobindo brings out the connection between the calming of the being and the illumination of the intelligence:

In this calm, right knowledge comes. . error begins to fall away and, so long as desire does not stir again, clarity establishes itself in the higher stratum of the consciousness compelling peace and joy in the lower. Right knowledge becomes the infallible source of right action. Yogah karmasu kauśalam ["Yoga is skill in works," Bhagavadgittā 2.50] (1998, p. 58).

The clarity that comes with calm, as described here, is reminiscent of the right "deliberation" or "reflection" which, according to the Great Learning, becomes possible once "peaceful repose" is achieved and leads in turn to "attainment." Wang Yangming explains:

Being in peaceful repose, whenever a thought arises or an event acts upon it, the mind with its innate knowledge will thoroughly sift and carefully examine whether or not the thought or event is in accord with the highest good, and thus the mind can deliberate. With deliberation, every decision will be excellent, and every act will be proper, and in this way the highest good will be attained (CHAN, 1969, pp. 662-63).

\section{Rectifying the Mind and Purifying the Will}

In the Confucian view of things, the "highest good" is not something that can be attained by an individual in isolation from society, for then it would be incomplete and not the highest. Accordingly, the Great Learning proceeds from its brief account of the psychological discipline just described to an equally concise and systematic listing of eight steps relating the inner life to the outer world. Unlike the previous series, this is apparently intended to be understood not so much as a temporal sequence as a logical analysis of the interdependence among elements of a single process. At least this is how Wang Yangming takes it: "While the order of the tasks involves a sequence of first and last, in substance they are one and cannot be so separated" (Chan, 1969, p. 666).

The steps are presented twice, the second time with the order reversed. The first enumeration begins with those pertaining to the relationship between the individual and society: "The ancients who wished to manifest their clear character to the world would first bring order to their states. Those who wished to bring order to their states would first regulate their families" (Chan, 1969, p. 86). Since Wang passes over this part of the program without comment, we need not dwell on it now. What immediately concerns us is the steps that follow: 
Those who wished to regulate their families would first cultivate their personal lives. Those who wished to cultivate their personal lives would first rectify their minds. Those who wished to rectify their minds would first make their wills sincere. Those who wished to make their wills sincere would first extend their knowledge. The extension of knowledge consists in the investigation of things (CHAN, 1969, p. 86).

At the heart of Wang Yangming's detailed interpretation of this passage is his explanation of the interconnections between rectifying the mind, making the will sincere, and extending knowledge. First of all, he points out:

Human nature being universally good, the original substance of the mind is correct. How is it that any effort is required to rectify the mind? The reason is that, while the original substance of the mind is originally correct, incorrectness enters when one's thoughts and will are in operation. Therefore he who wishes to rectify his mind must rectify it in connection with the operation of his thoughts and will (CHAN, 1969, p. 664).

When we try to make the will sincere, the problem as Wang sees it is that "unless there is a way to make clear the distinction between good and evil, there will be a confusion of truth and untruth. In that case, even if one wants to make his will sincere, he cannot do so." Consequently, the extension of knowledge becomes the crux of the matter. Wang clarifies what this means: "The extension of knowledge is not what later scholars understand as enriching and widening knowledge. It is simply extending one's innate knowledge of the good to the utmost." This "innate knowledge of the good" is liángzhī, the "intuition of good" discussed above. Although this faculty already exists in us and only needs to be uncovered, the knowledge it gives has also to be acted upon. The principal obstacle to doing so is evidently the same "selfish desires" (sìyù 私欲) which, as we have seen, have to be expelled in order to "manifest the clear character" (Chan, 1969, p. 66o).

In the Bhagavadgit ä, Arjuna asks: "what is this in us that drives a man to sin, as if by force, even against his own struggling will?" Krishna replies that it is desire, the "eternal enemy" of knowledge, which is obscured by it "as a fire is covered over by smoke, as a mirror by dust" (Roy, 2009, pp. 84-85). Similarly, Angle mentions "Wang's use of metaphors like the sun obscured by clouds, pure gold which can be tainted, and a perfect mirror marred by dust: all suggest that a fully formed moral faculty lies within each of us, though in each case its functioning is impaired" (2009, p. 116).

In Sri Aurobindo's integral Yoga, the elimination of desire and ego is part of the discipline of purification on which everything else depends. 
Purification is the subject of several chapters of The Synthesis of Yoga, including "Purification - The Lower Mentality" and "Purification Intelligence and Will" (1999, pp. 654-73). The processes explained in these two chapters can be correlated roughly with rectifying the mind and making the will sincere in the Confucian program outlined in the Great Learning. While the topic is too large to enter into here, what Sri Aurobindo means by "purity" must be made clear. For it is "not a negative, prohibitory, passive or quietistic, but a positive, affirmative, active purity" which is sought as the condition of "a total, unabated, even an increased and more powerful action" (1999, p. 643).

Two types of impurity have to be dealt with. The first is the egoistic working of each part of our being, distorting the fulfilment of its proper role. The second is the interference of any part of our being with the right functioning of other parts, especially the higher faculties. Thus, the life-force has the legitimate function of enjoyment; but the egoistic nature of its seeking for it not only vitiates the enjoyment itself but deforms our thought-process "so that we judge and reason according to our desires and prepossessions and not with the disinterested impartiality of a pure judgment and the rectitude of a reason which seeks only to distinguish truth and understand rightly the objects of its workings" (1999, p. 646). It is evidently a similar perception that led the author

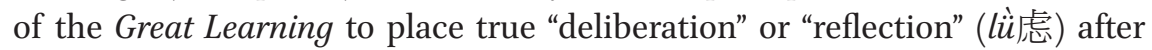
three preliminary stages which bring about a progressive tranquillization of the disturbances in our subjective being that ordinarily hamper our ability to see things as they are.

\section{$7 \quad$ Self-Cultivation and Integral Education}

After listing the "eight steps" in the order we have seen, the Great Learning turns them around, beginning with the investigation of things and ending with "peace throughout the world" (literally, "under heaven", tiānxià ping 天下平). The psychological steps in the series are linked to those concerned with society and politics by the step that occurs in the middle, "cultivation of the personal life" (xiūshēn 修身). Wang Yangming takes the "person" here to refer to "the physical functioning of the mind" (Chan, 1969, p. 664). That would explain why this step mediates between the inner life and the outer. But the Great Learning goes on to speak again of xiüshēn in what appears to be a broader sense, encompassing the whole psychological part of the process, when it says: "From the Son of Heaven down to the common people, all must regard cultivation of the personal life as the root or foundation" (Chan, 1969, p. 87). 
Often translated "self-cultivation," xiūshēn in this sense is frequently regarded as central to Confucianism. Heehs sums up a general consensus:

Confucian philosophers emphasized different aspects of the master's teachings but they all remained true to his core beliefs: through self-cultivation human beings can develop goodness and eventually become sages; a vanguard of cultivated elites is needed to promote goodness among the people; the wise and virtuous ruler creates the right conditions for a harmonious society.... Self-cultivation requires an inward turn but its results must be directed outward (2019, p. 48).

In India, the word for such self-cultivation is Yoga, defined by Sri Aurobindo as "a methodised effort towards self-perfection by the expression of the secret potentialities latent in the being" (1999, p.6). Among these latent potentialities is an "intuitive mind" which must "awaken in us" (1999, p. 456). Once it is awakened, we must "extend the action of the intuition and make it more constant, more persistent and regular and all-embracing until it is so intimate and normal to our being that it can take up all the action now done by the ordinary mind" (1999, p. 802). This extension of intuitive knowledge - Wang's zhi liángzh $i$ 致良知 - depends on the intuitive mind purifying itself progressively "from the invasion of egoism, self-interest, desire, passion and all kinds of self-will... Such was the supreme aim of the ancient sages who had the wisdom which rational man and rational society have rejected" (1997b, p. 154).

Despite the difficulty of this ideal and the rarity of acknowledged instances of its attainment, the Great Learning speaks of self-cultivation in relation to "the common people." As Bresciani (2016) points out, from Zhu Xi's time onward the Great Learning became "the keystone of the whole social, political, and educational system." Wang Yangming insists that "even an ordinary person. .. can also become a sage" (Angle, 2009, p.19). This agrees with Sri Aurobindo's vision of the future of humanity, in which the increasingly widespread development of the rational mind through universal education of the now familiar kind would be a preparation for a further stage in human progress. From this point of view the growing interest in integral education, inspired by the ideas of such luminaries as Wang Yangming and Sri Aurobindo, is a heartening sign.

In a series of articles on education, Sri Aurobindo observes that such education must include not only the training of all the normal human faculties, but also cultivation of the powers of a "layer of faculty which, not as yet entirely developed in man, is attaining gradually to a wider development and more perfect evolution" (2003, p. 387). These powers are those of the intuitive mind. Sri Aurobindo goes on to say about them: 
These powers are rare in their higher development, though many possess them imperfectly or by flashes. They are still greatly distrusted by the critical reason of mankind because of the admixture of error, caprice and a biased imagination which obstructs and distorts their perfect workings. Yet it is clear that humanity could not have advanced to its present stage if it had not been for the help of these faculties, and it is a question with which educationists have not yet grappled, what is to be done with this mighty and baffling element.... Faculties so important to humanity cannot be left out of our consideration. ... Their imperfect development must be perfected, the admixture of error, caprice and biased fancifulness must be carefully and wisely removed (2003, pp. 387-388).

Perhaps the time has come when our thinking on education can begin to take such ideas into account. In this area, given the long history of methods of self-cultivation in civilizations such as those of China and India, one might expect to see Asia take the lead.

\section{References}

Angle, S. C. (2009). Sagehood: The contemporary significance of Neo-Confucian philosophy. New York: Oxford University Press.

Aurobindo, Sri. (1997a). Essays on the Gita. Pondicherry: Sri Aurobindo Ashram.

Aurobindo, Sri. (1997b). The human cycle; The ideal of human unity; War and selfdetermination. Pondicherry: Sri Aurobindo Ashram.

Aurobindo, Sri. (1998). Essays in philosophy and yoga: Shorter works 1910-1950. Pondicherry: Sri Aurobindo Ashram.

Aurobindo, Sri. (1999). The synthesis of yoga. Pondicherry: Sri Aurobindo Ashram.

Aurobindo, Sri. (2003). Early cultural writings. Pondicherry: Sri Aurobindo Ashram.

Aurobindo, Sri. (2005). The life divine. Pondicherry: Sri Aurobindo Ashram.

Bresciani, U. (2016). Wang Yangming:An essential biography. E. Book: Passerino Editore.

Chan, W. (1969). A source book in Chinese philosophy. Princeton, NJ: Princeton University Press.

Heehs, P. (2019). Spirituality without God: A global history of thought and practice. London: Bloomsbury Academic.

Roy, A., ed. (2009). The message of the Gita as interpreted by Sri Aurobindo. Pondicherry: Sri Aurobindo Ashram.

Yao, X. (2000). An introduction to Confucianism. Cambridge, UK: Cambridge University Press. 